\title{
PCR DETECTION OF CTX-M GENES CODING ANTIBIOTIC RESISTANCE IN Klebsiella spp. ISOLATES IN AL-NAJAF PROVINCE, IRAQ
}

\author{
AL-MUHANNA A.S. AND AL-MAKHZOOMY T.A.* \\ Department of Laboratory Investigation, College of Science, University of Kufa, Najaf, Iraq. \\ *Corresponding Author: Email- taghreedalmakhzoomy@gmail.com
}

Received: September 09, 2013; Accepted: October 14, 2013

\begin{abstract}
One hundred and fifty five of Gram-negative-lactose fermented bacteria grown on MacConkey agar were collected from two main hospitals in Al- Najaf province. The isolates were identified according to cultural characteristics, biochemical activities and Vitick -2 system. 43 $(27.7 \%)$ isolates were identified as Klebsiella spp. Isolates, represented by $35(81.3 \%)$ isolates K. pneumoniae subsp. aerogenes, $4(9.3 \%)$ isolates Klebsiella pneumoniae subsp. pneumoniae, $2(4.6 \%)$ isolates Klebsiella oxytoca, as well as one isolate for each of K. pneumoniae subsp. ozaenae and K. pneumoniae subsp. rhinoscleromatis. The susceptibility of Klebsiellae isolates to 20 antibiotics were tested, using disc diffusion method; the results have revealed that Klebsiellae isolates were highly resistant to most common antibiotics. The ability of Klebsiellae isolates to produces extended $\beta$-lactamase were tested, the results have revealed that $26(60.4 \%)$ isolates produce ESBLs. The ability of Klebsiellae isolates to have CTX-M gene was tested; PCR amplification results have shown that 15 of Klebsiellae isolates were possess CTX$M$ lactamase gene.
\end{abstract}

Keywords- Klebsiella, $\beta$-lactamase, CTX-M gen

Citation: Al-Muhanna A.S. and Al-Makhzoomy T.A. (2013) PCR Detection of CTX-M Genes Coding Antibiotic Resistance in Klebsiella spp. Isolates in Al-Najaf Province, Iraq. International Journal of Microbiology Research, ISSN: 0975-5276 \& E-ISSN: 0975-9174, Volume 5, Issue 6, pp.-490-493.

Copyright: Copyright@2013 Al-Muhanna A.S. and Al-Makhzoomy T.A. This is an open-access article distributed under the terms of the Creative Commons Attribution License, which permits unrestricted use, distribution and reproduction in any medium, provided the original author and source are credited.

\section{Introduction}

Klebsiella is straight gram-negative rods, usually arranged singly, in pairs or in short chains, non-motile, facultative anaerobic bacteria which has both a respiratory and fermentative type of metabolism. Klebsiella spp. exhibit a very mucoid growth due to the large polysaccharide capsule [1].

The normal habitat of this bacteria is the intestinal tract of human and animal, but may be transferred to another site causing a wide range of infections, such as burns, wounds, respiratory tract and urinary tract infections; these infections become difficult to be treated because of the increased ability of Klebsiellae to resist different types of antibiotics [2].

The resistance was mediated by several mechanisms, the important one of which is the production of enzymes encoded by several genes that are carried on some bacterial plasmids, $\beta$-lactamase and extended spectrum $\beta$-lactamase. Extended spectrum $\beta$ lactamases are mostly plasmid-mediated enzymes capable of hydrolyzing and inactivating a wide variety of $\beta$-lactam antibiotics, including different types of penicillins and cephalosporines [3,4].

Recently, Klebsiella spp. considered as serious pathogen especially in hospital acquired infections because of their ability to resist a wide variety of antibiotics [5]. K. pneumoniae is regarded as the highest prevalence of ESBLs followed by Enterobacter cloacae and $E$. coli. The cefotaxime resistance was due to enzymes named cefotaximases (CTX-M). However, the CTX-Ms appeared a higher activity against cefotaxime than to ceftazidime $[6,7]$.

The bla CTX-M gene variants exhibit less than $40 \%$ of identity to bla SHV and bla TEM [8]. Different properties are involved in the cefotaxime-hydrolysing activity of the bla CTX-M genes. The most important amino acids residues for the ESBL activity of the CTX-M $\beta$ lactamases are Asn104, Ser237, Asp240 and Arg276 [9]. In the late 1990s, seven different blaCTX-M genes had been described, but the number of genes have been grown rapidly and now over 80 different variants have been detected [10].

The CTX-M enzymes have been detected in a variety of Enterobacteriaceae species, from widely separated geographical regions. However, the CTX-M variants are mostly detected in $E$. coli, $S$. typhimurium, $K$. pneumoniae and Proteus mirabilis [11]. $\beta$ lactamases of bla CTX-M-1, bla CTX-M-9 and bla CTX-M-14 type are the most common gene types predominant in Europe [12]

The increased prevalence of the isolates-producing ESBL has created an urgent need for laboratory testing methods that will accurately identify the presence of these enzymes in clinical isolates [4]. Many institutes have been published to detect the ESBLs in clinical isolates, including double disk synergy test and combination disk methods, in addition to molecular detection methods including DNA probes, Oligonucleotide typing and gene sequencing have been used to identify the ESBLs. However, the simplest and most com- 
mon molecular method has been used to detect the presence of $\beta$ lactamases genes is the polymerase chain reaction (PCR) via specific oligonucleotide primers which can be chosen from the sequences available in the public databases such as Genbank [13].

For these reasons, the aim of the study was published to detected the genes encoding $\beta$-lactam antibiotic resistance and comparison of genes percentages, via Isolation and identification of Klebsiella spp. isolates. Phenotypic detection for $\beta$-lactamase enzymeproducing bacterial isolates and detecting the existence of $\beta$ lactamase- genes by PCR technique.

\section{Material and Methods}

\section{Specimens Collection}

One hundred and fifty five Gram-negative lactose fermenting isolates grown on MacConkey agar were collected from two hospital in Najaf province, Alsader Teaching Hospital and Alzahra Teaching Hospital. The isolates are composed of 64 burns infections, 22, 44 and 25 isolates from wounds, urinary tract and respiratory tract infections respectively. From those, 63 isolates from males and 92 from females. The specimens were transferred immediately to the laboratory for culture and identification.

\section{Identification of Klebsiella spp. Isolates}

The bacterial isolates were identified according to the cultural and biochemical properties. Klebsiellae isolates were distinguished post growth on solid medium. It produces large, smooth, with pink color (lactose fermented), elevated and mucoid colony on MacConkey. Furthermore, the biochemical tests were performed for the identification of Klebsiellae isolates from other isolates. These tests included Indole test, Methyl red test, Voges-proskaur test, Simmon's Citrate test, Triple Sugar Iron test, Urease test, and Motility test [5].

\section{Antimicrobial Susptibility Test}

Disk diffusion method was performed to test the susceptibility of Klebsiella spp. isolates to common antibiotics on Mueller-Hinton agar, with an inoculum equal to $0.5 \mathrm{McF}$ arland turbidity according to CLSI [14]. The plates were incubated at $37^{\circ} \mathrm{C}$ for $18-24 \mathrm{hrs}$. and the inhibition zone diameters around the antibiotic discs were measured.

\section{Detection of ESBL Producing Isolates}

The modified double-disc synergy test (m-DDST) was used to detect the extended spectrum $\beta$-lactamase-producing isolates, aztreonam, ceftazidime, cefotaxime and ceftriaxone discs $(30 \mathrm{mg})$ were placed around an amoxicillin-clavulanic acid disc $(10 \mathrm{mg})$ at interdisc distances (centre to centre) of $20 \mathrm{~mm}$ on Muller-Hinton agar inoculated by bacterial suspension equal to $0.5 \mathrm{McF}$ arland, a clear extension of the edge of the aztreonam, ceftazidime, cefotaxime and ceftriaxone discs inhibition zone towards the disc containing clavulanic acid was interpreted as positive for ESBL production [15].

\section{Detection of CTX-M $\beta$-lactamase Genes (PCR Amplification)}

The method descried by Paterson, et al [13] was used to perform PCR amplification. Five $\mu \mathrm{l}$ of bacterial DNA has been used as a template, 40 Pico moles of each primer (Alpha DNA, Canada), $5 \mu \mathrm{l}$ of $2 X$ Go Taq Green master mix (Promega, USA) (consist of Go Taq DNA polymerase $400 \mu \mathrm{M}$ of each dNTP, $3 \mathrm{mM} \mathrm{MgCl}$ 2, reaction buffer ( $\mathrm{pH}=8)$, yellow and blue loading dyes), and $5 \mu$ of nucleasefree water (Promega, USA), given a total PCR reaction volume of $25 \mu$ l. The oligonucleotide PCR primers specific for the $\beta$-lactamase genes and PCR products length were

\section{Result}

A total of one hundred and fifty five Gram-negative lactose fermented isolates grown on MacConkey agar were collected from two hospitals in Al Najaf province 129 isolates (83.2\%) from Al-Sader teaching hospital and $25(16.8 \%)$ isolates from AL-Zahra teaching hospital [Table-1]. 92(59.3\%) isolates from females and 63(40.7\%) from males, the isolates were represented by $64(41.3 \%)$ from burns infections and $44(28.4 \%), 25(16.1 \%) \& 22(14.2 \%)$ from urinary tract, respiratory tract and wounds infections respectively [Table-1]. The isolates have been collected from two groups of patients, 105 $(67.7 \%)$ isolates from hospitalized patients and $50(32.3 \%)$ from outpatients. However, 43 isolates have been distinguished as Klebsiellae among the $155 \mathrm{Gram}$-negative clinical bacterial isolates.

The results revealed that $K$. pneumoniae subspecies aerogenes was identified in $35(81.4 \%)$ isolates from the total number of Klebsiella spp. isolates [Table-2]. K. pneumoniae subsp. pneumoniae was recorded in $4(9.4 \%)$ isolates, whereas $K$. pneumoniae subsp. ozanae and subsp. rhinoscleromatis were identified in 1 $(2.3 \%)$ for each one. K. oxytoca was recorded in $2(4.6 \%)$ isolates from the total number of Klebsiella spp.

The results of Klebsiella isolates to antibiotic sensitivity have clarified that the Klebsiellae isolates showed high resistance to most common antibiotics of $\beta$-lactams, aminoglycosides, tetracyclines, quinolones, sulfonamides and others.

\section{Detection of CTX-M $\beta$-lactamases Producing Isolates}

The determination of ESBLs-producing isolates was performed using double disk synergy test (DDST); the synergism was determined between augmentin (amoxyclav) and members of the third generation cephalosporins (ceftazidime, cefotaxime and ceftriaxone) The results revealed that $26(60.4 \%)$ isolates gave positive ESBLs production test, versus $17(39.6 \%)$ gave negative results, since the inhibition zone of synergism has been recognized clearly [Fig-1].

Table 1- Distribution of Bacterial Isolates According to Hospitals

\begin{tabular}{|c|c|c|c|c|c|c|c|c|}
\hline \multirow{2}{*}{ Infection } & \multirow{2}{*}{ Hospital } & \multicolumn{2}{|c|}{ Alsader } & \multicolumn{2}{|c|}{ Alzahra } & \multicolumn{2}{|c|}{ Total } & \multirow{2}{*}{ Total } \\
\hline & & Positive & Negative & Positive & Negative & Positive & Negative & \\
\hline \multirow{2}{*}{ Burns infections } & Hospitalized patients & 17 & 47 & -- & -- & \multirow{2}{*}{17} & \multirow{2}{*}{47} & \multirow{2}{*}{64} \\
\hline & Out patients & -- & -- & -- & -- & & & \\
\hline \multirow{2}{*}{ Urinary tract infections } & Hospitalized patients & 1 & 3 & 1 & 2 & \multirow{2}{*}{14} & \multirow{2}{*}{30} & \multirow{2}{*}{44} \\
\hline & Out patients & 8 & 14 & 4 & 12 & & & \\
\hline \multirow{2}{*}{ Respiratory tract infections } & Hospitalized patients & 3 & 10 & -- & 4 & \multirow{2}{*}{5} & \multirow{2}{*}{20} & \multirow{2}{*}{25} \\
\hline & Out patients & 1 & 4 & 1 & 2 & & & \\
\hline \multirow{2}{*}{ Wounds infections } & Hospitalized patients & 7 & 10 & -- & -- & \multirow{2}{*}{7} & \multirow{2}{*}{14} & \multirow{2}{*}{22} \\
\hline & Out patients & -- & 4 & -- & -- & & & \\
\hline \multirow{2}{*}{ Total } & & 37 & 92 & 6 & 19 & 43 & 112 & 155 \\
\hline & & \multicolumn{2}{|c|}{129} & \multicolumn{2}{|c|}{26} & \multicolumn{2}{|c|}{155} & 150 \\
\hline
\end{tabular}


Al-Muhanna A.S. and Al-Makhzoomy T.A.

Table 2- Distribution of Klebsiella spp. According to Infection Sites

\begin{tabular}{|c|c|c|c|c|c|c|}
\hline \multirow{3}{*}{ Infection site } & \multicolumn{4}{|c|}{ Bacteria } & \multirow{3}{*}{ K. oxytoca } & \multirow{3}{*}{ Total } \\
\hline & \multicolumn{4}{|c|}{ K. pneumoniae subspecies } & & \\
\hline & $\mathrm{K}$. aerogenes & K. pneumoniae & K. ozaenae & K. rhinoscleromatis & & \\
\hline Burns & 15 & 1 & 1 & -- & -- & 17 \\
\hline Wounds & 6 & 1 & -- & -- & - & 7 \\
\hline Urinary tract infection & 12 & 1 & -- & 1 & -- & 14 \\
\hline Respiratory tract infection & 2 & 1 & -- & -- & 2 & 5 \\
\hline Total & 35 & 4 & 1 & 1 & 2 & \\
\hline$\%$ & $81.50 \%$ & $9.40 \%$ & $2.30 \%$ & $2.30 \%$ & $4.60 \%$ & 43 \\
\hline
\end{tabular}

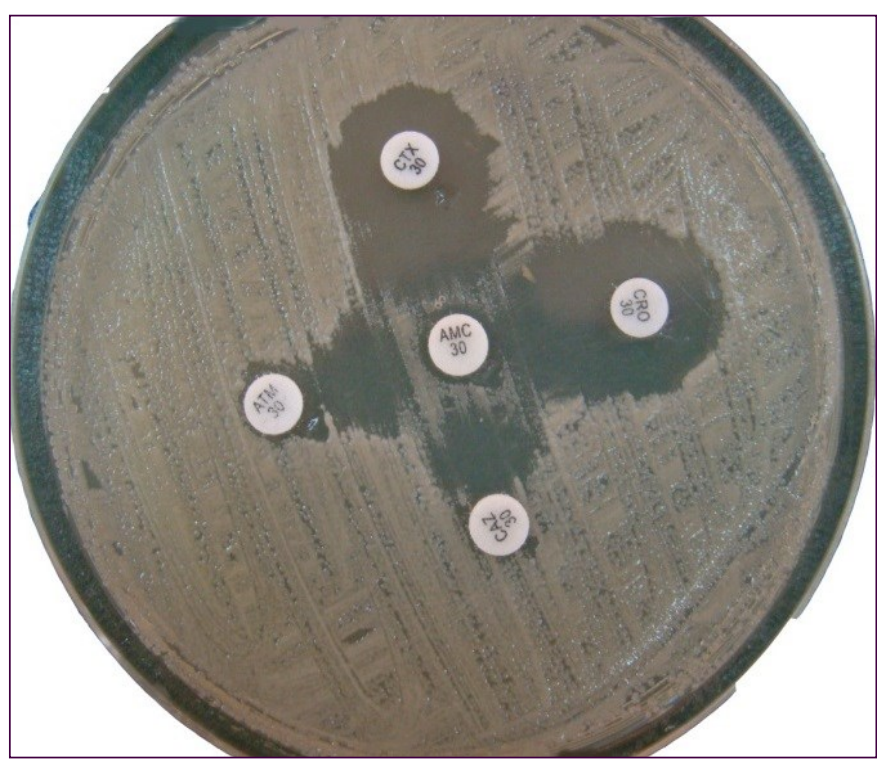

Fig. 1- Double disc synergy test. A/ Positive result of ESBLs production in Klebsiellae, B/ Negative result

Isolates that produce ESBLs were predominant more frequently among burns infections in $11(42.3 \%)$ isolates followed by $7(26.9 \%)$ of UTI, $5(19.2 \%)$ and $3(11.6 \%)$ in wound infections and respiratory tract infections respectively [Table-3].

\section{PCR Detection of $\beta$-lactamases}

Polymerase chain reaction technique has been used to amplify genes encoding the CTX-M $\beta$-lactamases from genomic DNA of all Klebsiella spp. isolates with specific forward and reverse primers; the lengths of amplified genes was $566 \mathrm{bp}$, The results of $\beta$ lactamase genes detection clarify that 15 isolates $(57.7 \%)$ of ESBLs producers carrying CTX-M gene (represented by $1,4,11,14,16,20$, $23,27,29,34,35,38,39,42,43$ isolates) [Fig-2].

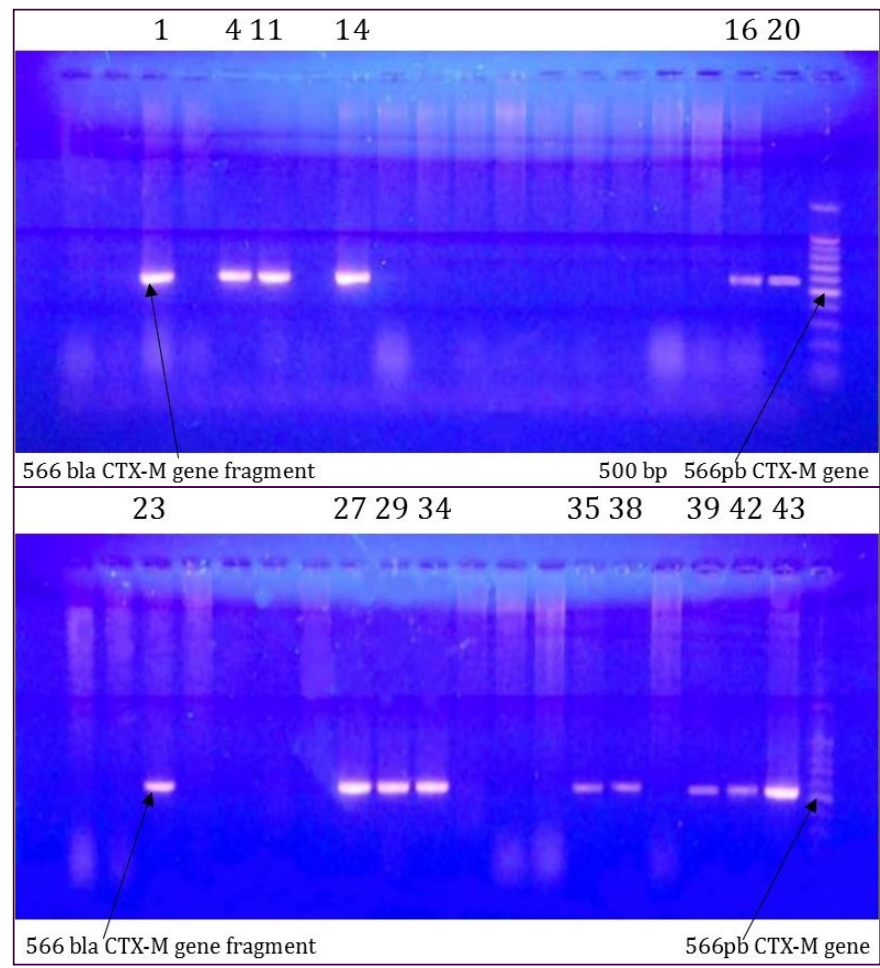

Fig. 2- PCR amplification of CTX-M gene of Klebsiella isolates

Table 3- prevalence of ESBLs- producing Klebsiella spp.

\begin{tabular}{|c|c|c|c|c|c|c|c|c|c|c|}
\hline \multirow{3}{*}{ Hospital } & \multicolumn{8}{|c|}{ Infection } & \multirow{2}{*}{\multicolumn{2}{|c|}{ Total $=43$}} \\
\hline & \multicolumn{2}{|c|}{ Burns } & \multicolumn{2}{|c|}{ Wounds } & \multicolumn{2}{|c|}{ Urinary tract infection } & \multicolumn{2}{|c|}{ Respiratory tract infection } & & \\
\hline & Positive & Negative & Positive & Negative & Positive & Negative & Positive & Negative & Positive & Negative \\
\hline Alsader & 11 & 6 & 5 & 2 & 3 & 6 & 3 & 1 & 22 & 15 \\
\hline Alzahra & -- & -- & -- & -- & 4 & 1 & -- & 1 & 4 & 2 \\
\hline Total & 11 & 6 & 5 & 2 & 7 & 7 & 3 & 2 & 26 & 17 \\
\hline$(\%)$ & $(42.30 \%)$ & 6 & $(19.20 \%)$ & 2 & $(26.90 \%)$ & 7 & $(11.60 \%)$ & 2 & $(60.46 \%)$ & $(39.53 \%)$ \\
\hline
\end{tabular}

\section{Discussion}

Klebsiella was very important opportunistic pathogen among gram negative bacilli causing a wide range of infections, such as burns, wounds, respiratory tract and urinary tract infections; these infections become difficult to be treated because of the increased ability of Klebsiellae to resist different types of antibiotics mediated by several mechanisms encoded by several genes that are carried on some bacterial plasmids [2]. For those resean 155 of gram negative isolates were sub cultured on suitable media, (including blood agar and MacConkey agar), and incubated at $37 \mathrm{C}^{\circ}$ for $18-24 \mathrm{hrs}$., after identification $27.7 \%$ of isolates have been identified as Klebsiellae spp. among the 155 Gram-negative clinical bacterial isolates. $K$. pneumoniae subspecies aerogenes was the most common member of Klebsiella spp. causing major infections, it was recorded in $81.3 \%$ of Klebsiella isolates.

The results of Klebsiella isolates to antibiotic sensitivity test have clarified that the Klebsiellae showed high resistance to most common antibiotics of $\beta$-lactams, aminoglycosides, tetracyclines, quinolones, sulfonamides and others Klebsiella spp. isolates which exhibit resistance to $\beta$-lactam antibiotics were suspected to be highly 
producers of ESBLs; therefore, all bacterial isolates undergo to ESBLs production test. The isolates that produce ESBLs were predominant among Klebsiella and they were more frequently among burns infections.

However, the detection rate of ESBLs-producing Klebsiellae isolated from clinical samples differ from each other. Screening for the existence of ESBLs among $K$. pneumoniae carried out in study of Taneja, et al [15], he reported that the highest rate of ESBLs production was found to be in Klebsiella spp. (51.2\%), followed by $E$. coli $(40.2 \%)$, Enterobacter aerogenes (33.4\%) and pseudomonas aeroginosa (27.9\%) isolates.

The incidence of ESBLs-producing strains among clinical isolates of Klebsiella pneumoniae have been on steady increase during few years ago, thus accounts about $17 \%$ of all nosocomial urinary tract infections [16].

\section{PCR Detection of $\beta$-lactamase (CTX-M)}

The genomic of Klebsiella was tested to determinant the CTX-M genes, using PCR technique with specific forward and reverse primer, $57.7 \%$ of $\beta$-lactamase producing isolates were caring CTX-M gene in their genomic DNA. The findings of the present study support the hypothesis that CTX-M gene is emerging as the dominant ESBL type in clinical isolates, these findings were agreement with the findings recorded by [13]. All CTX-M enzymes in Klebsiella pneumoniae and $E$. coli belonged to the CTX-M-1 as illustrated by restriction analysis [17].

In a multi-centric study from Russia, CTX-M gene was reported in $35.9 \%$ of $E$. coli and $34.9 \%$ of $K$. pneumoniae ESBLs isolates [18]. [19] reported $87 \%$ prevalence of CTX-M enzyme among ESBLs producing Klebsiellae in a tertiary care hospital of Greek.

\section{Conclusion}

Kebsiella pneumonia subsp. aerugenes was predominant in most of Klebsiella infections, the Klebsiella isolates was highly resistance for most of antibiotics and the CTX-M was predominant in Klebsiella isolates.

Conflict of Interest : None declared.

\section{References}

[1] Arora B. and Arora D.R. (2008) Practical Microbiology, Maharaja Agrasen Medical Collage, Agroha, Hisar, Haryana, India.

[2] Fluit A.C., Schmitz F.J. and Verhoef J. (2001) Int. J. Antimicrob. Agents, 18, 147-60.

[3] Oplustil C.P., Nunes R. \& Mendes C. (2001) Brazilian Journal of Infectious Diseases, 5(1), 8-12.

[4] Lautenbach E., Strom B.L., Bilker W.B., Patel J.B., Edelstein P.H. and Fishman N. (2001) Clin. Infect. Dis., 33, 1288-1294.

[5] Holt J.G., Krieg N.R., Sneath P.H.A., Staley J.T. and Williams S.T. (1994) Bergey's Manual of Determinative Bacteriology, Baltimore, Williams \& Wilkins, 181.

[6] Humeniuk C., Arlet G., Gautier V., Grimont P., Labia R. and Philippon A. (2002) Antimicrob. Agents Chemother., 46, 30453049.

[7] Iroha I.R., Amadi E.S., Adikwu M.U. and Esimone C.O. (2008) Int. J. Mol. Adv. Sci., 4(2), 46-49.

[8] Bonnet R., Recule C., Baraduc R., Chanal C., Sirot D., De Champs C., Sirot J. (2003) Journal of Antimicrobial Chemotherapy, 52(1), 29-35.
[9] Rasmussen B.A. and Bush K. (2004) Antimicrob. Agents Chemother., 41, 226-255.

[10]Jacoby G.A. and Bush K. (2009) Amino Acid Sequences for TEM, SHV and OXA Extended-Spectrum and Inhibitor Resistant ß-Lactamases, Lahey Clinic.

[11]Woodford N., Ward M.E., Kaufmann M.E., Turton J., Fagan E.J., James D., Johnson A.P., Pike R., Warner M., Cheasty T., Pearson A., Harry S., Leach J.B., Loughrey A., Lowes J.A., Warren R.E. and Livermore D.M. (2004) J. Antimicrob. Chemother., 54, 735-743.

[12]Livermore D.M., Canton R., Gniadkowski M., Nordmann P., Rossolini G.M., Arlet G., Ayala J., Coque T.M., Kern-Zdanowicz I., Luzzaro F., Poirel L. and Woodford N. (2007) Antimicrob. Chemother., 59, 165-174.

[13]Paterson D.L., Hujer K.M., Hujer A.M., Yeiser B., Bonomo M. D., Rice L.B., Bonomo R.A. (2003) Antimicrobial Agents and Chemotherapy, 47(11), 3554-3560.

[14]National Commttee for Clinical Laboratory Standard (2007) Performance Standards for Antimicrobial Susceptibility Testing, 9th Information Supplement, M100-S10, Wayne, PA, USA.

[15]Taneja N., Rao P., Arora J., Dogra A. (2008) Indian J. Med. Res., 127, 85-88.

[16]Iroha I.R., Ezeifeka G.O., Amadei E.S. and Umerzurike C.R. (2009) Res. J. Bio. Sci., 4(5), 588-592.

[17]Goyal A., Prasad K.N., Prasad A., Gupta S., Ghoshal U., Ayyagari A. (2009) Indian J. Med. Res., 129(6), 695-700.

[18]Edelstein M., Pimkin M., Palagin I., Edelstein I., Stratchounski L. (2003) Antimicrob. Agents Chemother., 47, 3724-3732.

[19]Pournaras S., Ikonomidis A., Kristo I., Tsakris A. and Maniatis A.N. (2004) J. Antimicrob. Chemother., 54, 574-575.

[20]Kim B.N., Ryu J., Kim Y.S. and Woo J.H. (2002) Eur. J. Clin. Microbiol. Infect. Dis., 21(6), 419-426. 